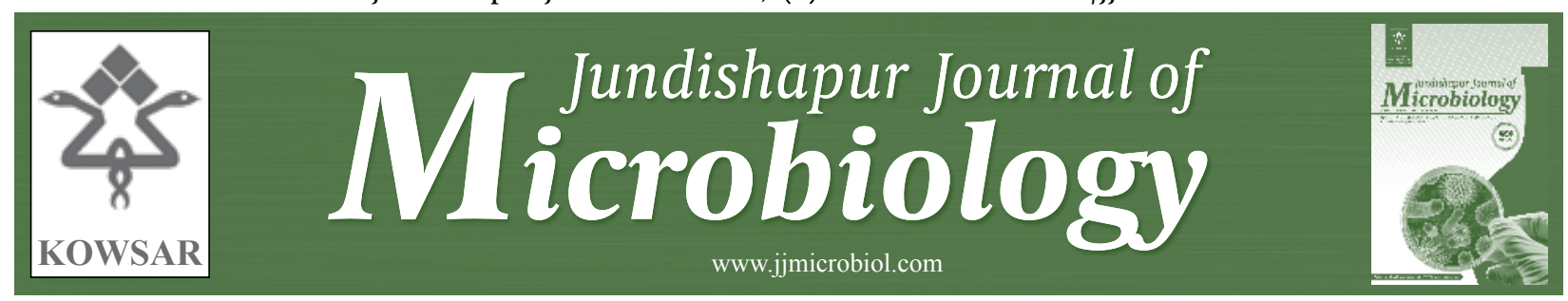

\title{
Restriction Fragment Length Polymorphism Genotyping of Human Staphylococcus aureus Isolates From Two Hospitals in Urmia Region of Iran Using the coa Gene
}

\author{
Reza Talebi-Satlou ${ }^{1}$, Malahat Ahmadi ${ }^{{ }^{*}}$, Habib Dastmalchi Saei ${ }^{1}$ \\ ${ }^{1}$ Department of Microbiology, Faculty of Veterinary Medicine, Urmia University, IR Iran
}

\begin{tabular}{|c|c|}
\hline A R T I C L E I N F O & A B S T R A C T \\
\hline Article type: & Background: Staphylococcus aureus has become an emerging public health concern. \\
\hline Original Article & Markers that differentiate tissue-specific lineages are needed to trace the sources of \\
\hline Article history: & objectives: The aims of this study were to determine the genotypic characteristics of \\
\hline Received: 01 Jul 2011 & S. aureus isolates that are associated with skin and urinary tract infections using poly- \\
\hline Revised: 01 Nov 2011 & morphisms in the coagulase gene. \\
\hline Accepted: 01 Nov 2011 & Materials and Methods: Coagulase gene variants among 26 S. aureus isolates from hu- \\
\hline Keywords: & tion of the repeat units encoding the hypervariable region of the coagulase gene. The \\
\hline Restriction Fragment Length Polymorphism & amplicons ranged from $490-790$ bp and were subjected to restriction fragment length \\
\hline Staphylococcus aureus & polymorphism (RFLp) analysis with HaeIII. \\
\hline \multirow[t]{4}{*}{ coa Gene } & Results: In total, 6 distinct RFLp banding patterns were observed, designated C1-C6.The \\
\hline & $\begin{array}{l}\mathrm{C} 1 \text { pattern predominated in skin and urine isolates. Notably, the } \mathrm{C} 3, \mathrm{C} 5 \text {, and } \mathrm{C} 6 \text { patterns } \\
\text { were present in isolates from urine, whereas the } \mathrm{C} 2 \text { and } \mathrm{C} 4 \text { genotypes were preferen- } \\
\text { tially detected in skin sample isolates. }\end{array}$ \\
\hline & $\begin{array}{l}\text { Conclusions: These data demonstrate the widespread prevalence of certain genotypes } \\
\text { and tissue-specific tendency of other genotypes, suggesting the existence of lineage-and } \\
\text { tissue-specific genes that mediate the development of tissue-specific pathogenicities of }\end{array}$ \\
\hline & Copyright @2012 Kowsar Corp. All rights reserved. \\
\hline
\end{tabular}

- Implication for health policy/practice/research/medical education:

Results of the current study also showed that the repeat region of coa gene can be useful for typing and grouping of skin and urinary tract associated $S$. aureus isolates.

Please cite this paper as:

Talebi-Satlou R, Ahmadi M, Dastmalchi Saei H. Restriction Fragment Length Polymorphism Genotyping of Human Staphylococcus aureus Isolates From Two Hospitals in Urmia Region of Iran Using the coa Gene.Jundishapur J Microbiol.2012;5(2):416-20. DOI: 10.5812/jjm.3522

\footnotetext{
1.Background

Staphylococcus aureus is a highly adaptable human pathogen that is responsible for many infections and fatalities worldwide. The interaction between S. aureus and its human host is complex and multifactorial, because it can colonize several niches in the host. This organism is the leading cause of skin and soft tissue infections (SS-

* Corresponding author: Malahat Ahmadi, Department of Microbiology, Faculty of Veterinary Medicine, Urmia University, P. O. Box 1177, Urmia, IR Iran; Tel: +98-4412972649, Fax: +98-4412771926, E-mail: Ahmadi12tr@ yahoo.com

DOI:10.5812/jjm.3522

Copyright $\odot 2012$ Kowsar Corp. All rights reserved.
}

TIs), including furuncles, carbuncles, cellulitis, and abscesses, in most countries (1-3). Several studies of patients with $S$. aureus bacteriuria (SABU) have reported S. aureus to be the primary urinary pathogen and SABU as a potential reservoir of invasive infection $(4,5)$.

The prevention and control of $S$. aureus infections depend initially on identifying the risk factors of the exposed population with regard to acquiring S. aureus, and also analysis of isolates by discriminatory bacterial DNA typing, to understand the transmission of this infectious organism. In many countries, S. aureus genotyping has become a part of ongoing surveillance systems and an important tool in the study of strain origin, clonal 
relatedness, and the epidemiology of outbreaks $(6,7)$. An analysis of hospitalized patients with nosocomial $S$. aureus SSTIs showed that different clones were responsible for all cases of SSTIs (8). Genetic variation between isolates from human skin and urinary tract infections has also been observed (9-11).

Historically, typing of $S$. aureus has relied primarily on strain phenotype (for example, susceptibility to bacteriophages or antibiotics), but over the past 2 decades, a variety of molecular typing methods have been developed, including phage typing, pulsed field gel electrophoresis (PFGE), binary typing, multilocus sequence typing (MLST), and PCR amplification of variable regions combined with restriction endonuclease analysis (12-16). Genotypic methods have the advantage over phenotypic methods of being independent of the expression of specific genes under artificial assay conditions (eg, laboratory media), because genotypes are relatively stable in nature compared with phenotype (biotype, serotype, antibiogram). Genotypic methods yield reproducible results, regardless of variations in laboratory assay conditions; they are rapid and do not require in vitro culture, allowing one to identify fastidious or unculturable organisms. In contrast to phenotypic methods, chromosomal DNA-based typing methods achieve near 100\% typability, because all bacteria contain DNA.

The discriminatory ability of genotypic versus phenotypic methods is also higher (17). Analyses of coagulaseencoding staphylococcal DNA genes have identified variable sequences in the 3 '-end coding region of allelic gene forms (18). DNA sequence analysis of the 3 '-end of the coagulase gene revealed heterogeneity in the region containing the $81 \mathrm{bp}$ tandem repeats encoding repeated 27-amino-acid sequences in the C-terminal region. PCR amplification of this region generated DNA fragments of various sizes that could be further discriminated by digestion with AluI (19). Therefore, amplification of the coagulase gene is considered a simple and accurate method of typing S. aureus from various sources $(15,19-23)$ and can be included in routine infection control programs in hospitals and epidemiological studies (20).

\section{Objectives}

The aims of this study were to determine the genotypic characteristics of $S$. aureus isolates that are associated with skin and urinary tract infections based on coagulase gene polymorphisms.

\section{Materials and Methods}

\subsection{Sample Collection and Bacterial Species Identification}

A total of 26 clinical isolates of $S$. aureus (16 from urine samples and 10 from skin) were recovered from patients suffering from urinary tract and skin wound infections in Urmia region, West Azerbaijan province, Iran. Urine samples and wound cultures (obtained from skin infections swabs) were collected on admission, and primary cultures were grown on mannitol salt agar plates (MSA, Merck, Germany), a selective medium for S. aureus. Each plate was examined for colonies that were morphologically consistent with S. aureus. Samples of putative S. aureus colonies were selected and reinoculated on blood agar plates to isolate pure colonies. These plates were confirmed visually to contain monotypic colonies on the following day. Monotypic isolates were stained by Gram's method; Gram-positive cocci were tested with $1 \%$ hydrogen peroxide for catalase activity. Catalase-positive isolates were subjected to tube coagulase test. Coagulase-positive isolates were frozen at $-70^{\circ} \mathrm{C}$ in cryopreservation tubes. Species-specific identification was also performed for all preserved isolates by amplification of the nuc gene, as described (24). DNA was prepared using a genomic DNA purification kit (Fermentas, Germany) per the manufacturer's recommendations.

\section{2. coa Polymerase Chain Reaction (PCR)}

Amplification of the 3' end of the coagulase gene was performed using primers reported by Hookey et al. (25): 5'- ATA GAG ATG CTG GTA CAG G -3' (bases 1513 to 1531) and 5'- GCT TCC GAT TGT TCG ATG C -3' (bases 2188 to 2168). The total reaction volume was $25 \mu \mathrm{L}$, performed as described (22) on a thermal cycler (CORBETT thermocycler, Model CP2-003, Australia) with the following program: a 45-s precycle at $94^{\circ} \mathrm{C}$, followed by 30 cycles $\left(20 \mathrm{~s}\right.$ at $94^{\circ} \mathrm{C}, 15 \mathrm{~s}$ at $57^{\circ} \mathrm{C}$, and $15 \mathrm{~s}$ at $70^{\circ} \mathrm{C}$ ). At the end of the program, the reaction mixture was maintained at $72^{\circ} \mathrm{C}$ for 2 minutes (26). The sizes of the PCR products (5-mL aliquot) were determined using the GeneRuler ${ }^{\mathrm{TM}} 100$ bp DNA ladder plus marker (Fermentas, Germany) by electrophoresis at $80 \mathrm{~V}$ for $1 \mathrm{~h}$ on $1.2 \%(\mathrm{wt} / \mathrm{vol}$ ) agarose gel with ethidium bromide $(0.5 \mu \mathrm{g} / \mathrm{mL})$. The reference strain ATCC 29213 was included as a positive control for the PCR assays and enzymatic digestion. For the negative control, sterile water was added instead of DNA.

\subsection{Hae III Digestion}

Ten microliters of PCR product was incubated with $6 \mathrm{U}$ Hae III at $37^{\circ} \mathrm{C}$ for $1 \mathrm{~h} 45 \mathrm{~min}$ in a water bath.

\section{Results}

According to conventional tests, all 26 cultures were also identified as $S$. aureus, by PCR amplification of the thermonuclease gene (nuc) using primer pairs per Brakstad et al.(24) and performed per Saei et al.(27). Amplicons of the nuc gene were uniform in size-approximately 279 bp (data not shown).

Amplification of 3' end region of coa generated 4 classes of bands, based on size, ranging from 410-790 bp (Figure 1). The 700-bp amplicon predominated in urine- and skin-origin isolates. HaeIII digestion of the PCR products produced 6 distinct RFLp patterns, designated C1-C6 (Figure 2). Pattern $\mathrm{C} 1$ was the dominant pattern, occurring in the majority of isolates (69.2\%). All S. aureus isolates were 
Figure 1. Amplicons for the Demonstration of Four Different Sizes of coa PCR Product.

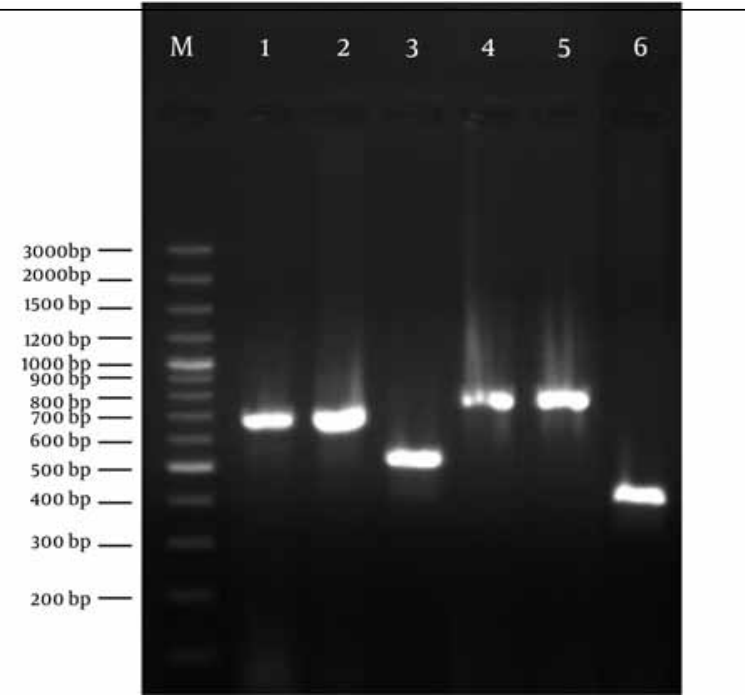

Lane M: size marker (GeneRuler ${ }^{\mathrm{TM}} 100$ bp DNA ladder plus). Lanes 1-2: an approximately $700 \mathrm{bp}-$ long S. aureus coagulase PCR product. Lane 3: $530 \mathrm{bp}-$ long product. Lanes 4-5: $790 \mathrm{bp}$-long product. Lane 6: $410 \mathrm{bp}$-long product

Figure 2. RFLP Patterns of the coa amplicons After Digestion With Endonuclease HaeIII.

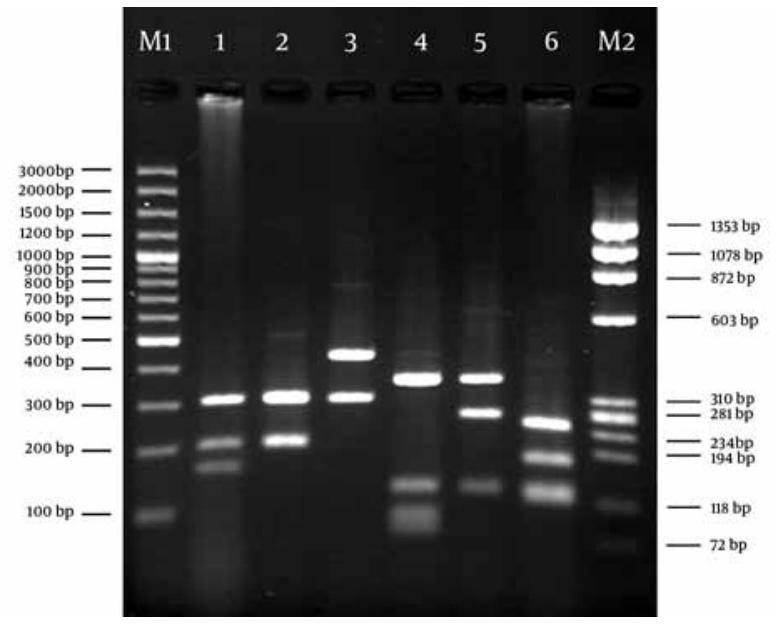

Lane M1: GeneRuler ${ }^{\mathrm{TM}} 100$ bp DNA Ladder Plus. Lanes 1-6: RFLP Patterns C1, C2, C3, C4, C5, and C6, Respectively. Lane M2: ФX174 DNA/HaeIII Marker

typable using this technique. As shown in Table 1, the 700-and 790-bp amplicons formed 2 patterns after HaeIII digestion, whereas the 410- and 530-bp fragments gener- ated a unique patterns-C2 and C6, respectively. Several coa types were detected in urinary tract and skin tissue, but $\mathrm{C} 1$ was dominant and present in both tissues. Some types were detected only in skin ( $\mathrm{C} 2$ and $\mathrm{C} 4)$ or urine (C3, C5, and C6).

\section{Discussion}

A total of 26 S. aureus clinical isolates from skin and urine sources were studied to genotype the coa gene by PCR-RFLP. This efficient and reliable typing procedure is beneficial in developing efficient infection control measures in hospitals for staphylococcal infection (20). Molecular typing generated genetically distinct sets (C1-6) of S. aureus isolates. Yet, type $\mathrm{C} 1$ was responsible for $69.2 \%$ of all cases of skin and urinary tract infections, reflecting its prevalence. This finding suggests that a genetic subset of S. aureus isolates is particularly well adapted for causing infections in various parts of the human body. One explanation for this pattern relates to the genetic background, which differs substantially between strains, warranting further study of its function in effecting tissue adaptability and pathogenesis in skin and urinary tract infections. The existence of multiple virulence genes, such as adhesins, suggests that $\mathrm{C} 1$ isolates promotes infection and enhances their persistence in the urinary tract and skin.

Like antimicrobial peptides, fatty acids are induced in skin on injury or microbial stimulus through Toll-like receptor-dependent pathways $(28,29)$. In human sweat, secretory IgA, as well as IgG and IgE, have been detected (30). Secretory immunoglobulins of the skin cover surface structures of microorganisms and thus modify their adhesion and infectivity, resembling humoral immunity in mucous membranes (30). Bacteria, such as S. aureus, that colonize the skin and cause disease can resist host innate defenses through several mechanisms. Thus, the intractability of coa type $\mathrm{C} 1 \mathrm{~S}$. aureus to many effectors of innate defense in the skin explains its existence as the dominant etiological agent of infections in wounded skin in humans. Otsuka et al. (31) reported that the presence of bone-bound sialoprotein $(b b p)$ confers a strong capacity for adherence (colonization) to MRSA, reflecting a pandemic spread via skin-to-skin contact.

Recently, a group has identified the contribution of iron-responsive surface determinant A (IsdA) expression to the biophysical properties of the cell surface of S. aureus (32). By reducing the overall hydrophobicity of

\begin{tabular}{|c|c|c|c|c|c|c|c|}
\hline & \multirow{3}{*}{ Isolates, No. } & \multicolumn{6}{|c|}{ 3' End -Region of the coa Gene } \\
\hline & & \multirow{2}{*}{$\begin{array}{l}\mathbf{4 1 0} \\
\text { C6 }\end{array}$} & \multirow{2}{*}{$\begin{array}{l}\mathbf{5 3 0} \\
\mathrm{C} 2\end{array}$} & \multicolumn{2}{|c|}{700} & \multicolumn{2}{|c|}{790} \\
\hline & & & & $\mathrm{C} 1$ & $\mathrm{C} 4$ & C3 & $\mathrm{C} 5$ \\
\hline Urine & 16 & 2 & - & 12 & - & 1 & 1 \\
\hline Skin & 10 & - & 2 & 6 & 2 & - & - \\
\hline Total & 26 & 2 & 2 & 18 & 2 & 1 & 1 \\
\hline
\end{tabular}


the bacteria, IsdA blocks the action of antibacterial molecules in normal skin, including cathelicidin, $\beta$-defensin peptides, human sebum, and its constituent hydrophobic fatty acids. Consequently, IsdA promotes S. aureus survival on human skin-the first molecular resistance mechanism of the pathogen to host fatty acid defenses to be identified. On the other hand, the predominance of type $\mathrm{C} 1$ among skin isolates is likely attributed to the finding that the transmission of infection is a dynamic phenomenon, caused by frequent person-to-person contact, contamination of surfaces, and the sharing of personal hygiene items.

Toshkova et al. (33) also indicated the importance of nasal carriage of S. aureus in the development of human skin infections. Children colonized with MRSA may also be an important reservoir and source of transmission of SSTIs in the household (34). In a study by Ellis et al. (35), MRSA nasal carriage was recognized as a risk for MRSA SSTIs, and individuals who have been colonized with MRSA are at increased risk of subsequent infections. Previous studies have demonstrated that individuals with S. aureus bacteremia (36) and surgical site infections (37) are colonized in their nares with the same isolates $80 \%$ to $90 \%$ of the time, as determined by pulsed-field gel electrophoresis.

As shown, the majority of urine-associated isolates possessed the same pattern (C1). Many virulence factors might have contributed to this predominance. For example, the intracellular adhesion (icaA) gene may enhance the adherence of $S$. aureus to host cells of the urinary tract and play a pathogenic role in UTI (38). Also, hematogenous spread of $S$. aureus from other areas, such as skin, which may harbor the C1 type, is likely possible. Earlier studies documented S. aureus bacteriuria and bacteremia in $8.3 \%$ to $15 \%$ of the patient population $(5,39$, 40). Choi et al. (41) also found that S. aureus bacteriuria is frequently concomitant with $S$. aureus bacteremia. However, it is unknown whether $S$. aureus bacteriuria is caused via a hematogenous route from SAB or whether $S$. aureus bacteriuria itself leads to subsequent invasive infections. Additional large-scale studies using different molecular typing methods are necessary to confirm their association.

The C3, C5, and C6 genotypes were only detected in urine isolates, whereas $\mathrm{C} 2$ and $\mathrm{C} 4$ were only in skin, suggesting that specific selection has occurred in the skin and urinary tract. The environments of the skin and urinary tract differ markedly and might account for the degree of genetic divergence between the isolates studied. It has been reported that some clones of S. aureus have a greater tendency toward skin carriage, possibly due to the arginine catabolic mobile element, which might allow the strain to survive better at the low $\mathrm{pH}$ of the skin (42). The presence of combinations of virulence factors plays an important role in host and tissue specificity of $S$. aureus infections (43). Expanded genetic analyses are necessary to generate evidence of tissue specialization among S. aureus clonal groups associated with human infections.

In conclusion, we observed heterogeneity among skin- and urine-associated S. aureus isolates using coa gene polymorphisms, but only one type was dominant in both skin and urine samples. Our study also revealed the existence of tissue specialization among isolates. As a consequence, more emphasis might be placed on skin and urine samples when trying to detect colonization of dominant or rare types. Additional studies of $S$. aureus genotypes that are commonly associated with human infections are recommended to determine the role of genetic features in contributing to the tropism of certain clones in infecting specific tissues and causing a particular disease. Further studies on these aspects from different regions of the country must be performed to gain insight into the epidemiology of S. aureus in hospitals and develop preventive strategies. Finally, clinicians who treat patients with $S$. aureus urinary tract infections are recommended to inquire about recent urinary tract instrumentation and recent hospitalization with intravascular device use.

\section{Acknowledgments}

None declared.

\section{Financial Disclosure}

There is no Financial Disclosure.

\section{Funding/Support}

This study was financially supported by Urmia University, Urmia, Iran.

\section{References}

1. Bowler PG, Duerden BI, Armstrong DG. Wound microbiology and associated approaches to wound management. Clin Microbiol Rev. 2001;14 (2):244-69.

2. Gould IM. Antibiotics, skin and soft tissue infection and meticillin-resistant Staphylococcus aureus: cause and effect. Int J Antimicrob Agents. 2009;34 (Suppl 1):S8-11.

3. McCaig LF, McDonald LC, Mandal S, Jernigan DB. Staphylococcus aureus-associated skin and soft tissue infections in ambulatory care. Emerg Infect Dis. 2006;12 (11):1715-23.

4. Ekkelenkamp MB, Verhoef J, Bonten MJ. Quantifying the relationship between Staphylococcus aureus bacteremia and S. aureus bacteriuria: a retrospective analysis in a tertiary care hospital. Clin Infect Dis. 2007;44 (11):1457-9.

5. Muder RR, Brennen C, Rihs JD, Wagener MM, Obman A, Stout JE, et al. Isolation of Staphylococcus aureus from the urinary tract: association of isolation with symptomatic urinary tract infection and subsequent staphylococcal bacteremia. Clin Infect Dis. 2006;42 (1):46-50.

6. Byun DE, Kim SH, Shin JH, Suh SP, Ryang DW. Molecular epidemiologic analysis of Staphylococcus aureus isolated from clinical specimens. J Korean Med Sci. 1997;12 (3):190-8.

7. Tambic A, Power EG, Tambic T, Snur I, French GL. Epidemiological analysis of methicillin-resistant Staphylococcus aureus in a Zagreb Trauma Hospital using a randomly amplified polymorphic DNA-typing method. EurJ Clin Microbiol Infect Dis. 1999;18 (5):33540.

8. Gadepalli R, Dhawan B, Kapil A, Sreenivas V, Jais M, Gaind R, et al. 
Clinical and molecular characteristics of nosocomial meticillinresistant Staphylococcus aureus skin and soft tissue isolates from three Indian hospitals. J Hosp Infect. 2009;73 (3):253-63.

9. Araki M, Kariyama R, Monden K, Tsugawa M, Kumon H. Molecular epidemiological studies of Staphylococcus aureus in urinary tract infection.J Infect Chemother. 2002;8 (2):168-74.

10. Campbell SJ, Deshmukh HS, Nelson CL, Bae IG, Stryjewski ME, Federspiel JJ, et al. Genotypic characteristics of Staphylococcus aureus isolates from a multinational trial of complicated skin and skin structure infections.J Clin Microbiol. 2008;46 (2):678-84.

11. Salasia SIO, Khusnanz Z, Lammler C, Nirwati H. Pheno- and genotyping of Staphylococcus aureus isolated from human skin infections in Yogyakarta. IJ Biotec. 2003;6:612-20.

12. Enright MC, Robinson DA, Randle G, Feil EJ, Grundmann H, Spratt BG. The evolutionary history of methicillin-resistant Staphylococcus aureus (MRSA). Proc Natl Acad Sci U S A. 2002;99 (11):7687-92.

13. Mehndiratta PL, Bhalla P, Ahmed A, Sharma YD. Molecular typing of methicillin-resistant Staphylococcus aureus strains by PCR-RFLP of SPA gene: a reference laboratory perspective. Indian J Med Microbiol. 2009;27 (2):116-22.

14. Rabello RF, Moreira BM, Lopes RM, Teixeira LM, Riley LW, Castro AC. Multilocus sequence typing of Staphylococcus aureus isolates recovered from cows with mastitis in Brazilian dairy herds. J Med Microbiol. 2007;56 (Pt 11):1505-11.

15. Saei H, Ahmadi M. Discrimination of Staphylococcus aureus isolates on the basis of gene coding protein a using PCR-restriction enzyme analysis. Comp Clin Path. 2011:1-8.

16. Zadoks RN, van Leeuwen WB, Kreft D, Fox LK, Barkema HW, Schukken YH, et al. Comparison of Staphylococcus aureus isolates from bovine and human skin, milking equipment, and bovine milk by phage typing, pulsed-field gel electrophoresis, and binary typing. J Clin Microbiol. 2002;40 (11):3894-902.

17. Stepan J, Pantucek R, Doskar J. Molecular diagnostics of clinically important staphylococci. Folia Microbiol (Praha). 2004;49 (4):353-86.

18. Phonimdaeng P, O'Reilly M, Nowlan P, Bramley AJ, Foster TJ. The coagulase of Staphylococcus aureus 8325-4. Sequence analysis and virulence of site-specific coagulase-deficient mutants. Mol Microbiol.1990;4 (3):393-404.

19. Goh SH, Byrne SK, Zhang JL, Chow AW. Molecular typing of Staphylococcus aureus on the basis of coagulase gene polymorphisms. J Clin Microbiol.1992;30 (7):1642-5.

20. Himabindu M, Muthamilselvan DS, Bishi DK, Verma RSY. Molecular analysis of coagulase gene polymorphism in clinical isolates of methicilin resistant Staphylococcus aureus by restriction fragmentlength polymorphism based genotyping. Am J Infec Dis. 2009;5 (2):163-9.

21. Rodrigues da Silva E, da Silva N. Coagulase gene typing of Staphylococcus aureus isolated from cows with mastitis in southeastern Brazil. Can J Vet Res. 2005;69 (4):260-4.

22. Saei HD, Ahmadi M, Mardani K, Batavani RA. Molecular typing of Staphylococcus aureus isolated from bovine mastitis based on polymorphism of the coagulase gene in the north west of Iran. Vet Microbiol. 2009;137 (1-2):202-6.

23. Schlegelova J, Dendis M, Benedik J, Babak V, Rysanek D. Staphylococcus aureus isolates from dairy cows and humans on a farm differ in coagulase genotype. Vet Microbiol. 2003;92 (4):327-34.

24. Brakstad OG, Maeland JA, Tveten Y. Multiplex polymerase chain reaction for detection of genes for Staphylococcus aureus thermonuclease and methicillin resistance and correlation with oxacillin resistance. APMIS. 1993;101 (9):681-8.

25. Hookey JV, Richardson JF, Cookson BD. Molecular typing of Staphylococcus aureus based on PCR restriction fragment length polymorphism and DNA sequence analysis of the coagu- lase gene. J Clin Microbiol.1998;36 (4):1083-9.

26. Hookey JV, Edwards V, Cookson BD, Richardson JF. PCR-RFLP analysis of the coagulase gene of Staphylococcus aureus: application to the differentiation of epidemic and sporadic methicillin-resistant strains. J Hosp Infect. 1999;42 (3):205-12.

27. Saei HD. coa types and antimicrobial resistance profile of Staphylococcus aureus isolates from cases of bovine mastitis. Comp Clin Path. 2010:1-7.

28. Georgel P, Crozat K, Lauth X, Makrantonaki E, Seltmann H, Sovath $S$, et al. A toll-like receptor 2-responsive lipid effector pathway protects mammals against skin infections with gram-positive bacteria. Infect Immun. 2005;73 (8):4512-21.

29. Schauber J, Dorschner RA, Coda AB, Büchau AS, Liu PT, Kiken D, et al. Injury enhances TLR2 function and antimicrobial peptide expression through a vitamin D-dependent mechanism. J Clin Invest. 2007;117 (3):803-11.

30. Metze D, Kersten A, Jurecka W, Gebhart W. Immunoglobulins coat microorganisms of skin surface: a comparative immunohistochemical and ultrastructural study of cutaneous and oral microbial symbionts. Invest Dermatol. 1991;96 (4):439-45.

31. Otsuka T, Saito K, Dohmae S, Takano T, Higuchi W, Takizawa Y, et al. Key adhesin gene in community-acquired methicillinresistant Staphylococcus aureus. Biochem Biophys Res Commun. 2006;346 (4):1234-44.

32. Clarke SR, Mohamed R, Bian L, Routh AF, Kokai-Kun JF, Mond JJ, et al. The Staphylococcus aureus surface protein IsdA mediates resistance to innate defenses of human skin. Cell Host Microbe. 2007;1 (3):199-212.

33. Toshkova K, Annemuller C, Akineden O, Lammler C. The significance of nasal carriage of Staphylococcus aureus as risk factor for human skin infections. FEMS Microbiol Lett. 2001;202 (1):17-24.

34. Fritz SA, Epplin EK, Garbutt J, Storch GA. Skin infection in children colonized with community-associated methicillin-resistant Staphylococcus aureus. J Infect. 2009;59 (6):394-401.

35. Ellis MW, Hospenthal DR, Dooley DP, Gray PJ, Murray CK. Natural history of community-acquired methicillin-resistant Staphylococcus aureus colonization and infection in soldiers. Clin Infect Dis. 2004;39 (7):971-9.

36. Safdar N, Bradley EA. The risk of infection after nasal colonization with Staphylococcus aureus. Am J Med. 2008;121 (4):310-5.

37. von Eiff C, Becker K, Machka K, Stammer H, Peters G. Nasal carriage as a source of Staphylococcus aureus bacteremia. Study Group. N Engl J Med. 2001;344 (1):11-6.

38. Park HK, Woo SY, Jung YJ, Lee EO, Cha JE, Park HS, et al. Detection of Virulence Genes of Staphyloccus aureus and Staphylococcus epidermidis Isolated from Suprapubic Urine from Infants with Fever. J Bacteriol Virol. 2008;38 (4):189-96.

39. Arpi M, Renneberg J. The clinical significance of Staphylococcus aureus bacteriuria. JUrol. 1984;132 (4):697.

40. Huggan PJ, Murdoch DR, Gallagher K, Chambers ST. Concomitant Staphylococcus aureus bacteriuria is associated with poor clinical outcome in adults with S. aureus bacteraemia. J Hosp Infect. 2008;69 (4):345-9.

41. Choi SH, Lee SO, Choi JP, Lim SK, Chung JW, Jeong JY, et al. The clinical significance of concurrent Staphylococcus aureus bacteriuria in patients with S. aureus bacteremia. J Infect. 2009;59 (1):37-41.

42. Diep BA, Gill SR, Chang RF, Phan TH, Chen JH, Davidson MG, et al. Complete genome sequence of USA300, an epidemic clone of community-acquired meticillin-resistant Staphylococcus aureus. Lancet. 2006;367 (9512):731-9.

43. van Leeuwen WB, Melles DC, Alaidan A, Al-Ahdal M, Boelens HA, Snijders SV, et al. Host- and tissue-specific pathogenic traits of Staphylococcus aureus. J Bacteriol. 2005;187 (13):4584-91. 